霊長類研究 Primate Res. 15:93-99, 1999

資 料

調査地紹介：マハレ山塊国立公園（タンザニア連合共和国）

中村美知夫 ・伊藤詞子・坂巻哲也

京都大学大学院理学研究科生物科学専攻人類進化論研究室

本稿では, 地理, 植生, 動物相などをはじめと したマハレ山塊国立公園の一般的な情報を提供す る。マハレでのチンパンジー研究についての詳細 は, 人類進化論研究室のホームページにある論文 リスト (http: / / gorilla.zool.kyoto-u.ac.jp / ChimpHome/reference.html）を参照していただ

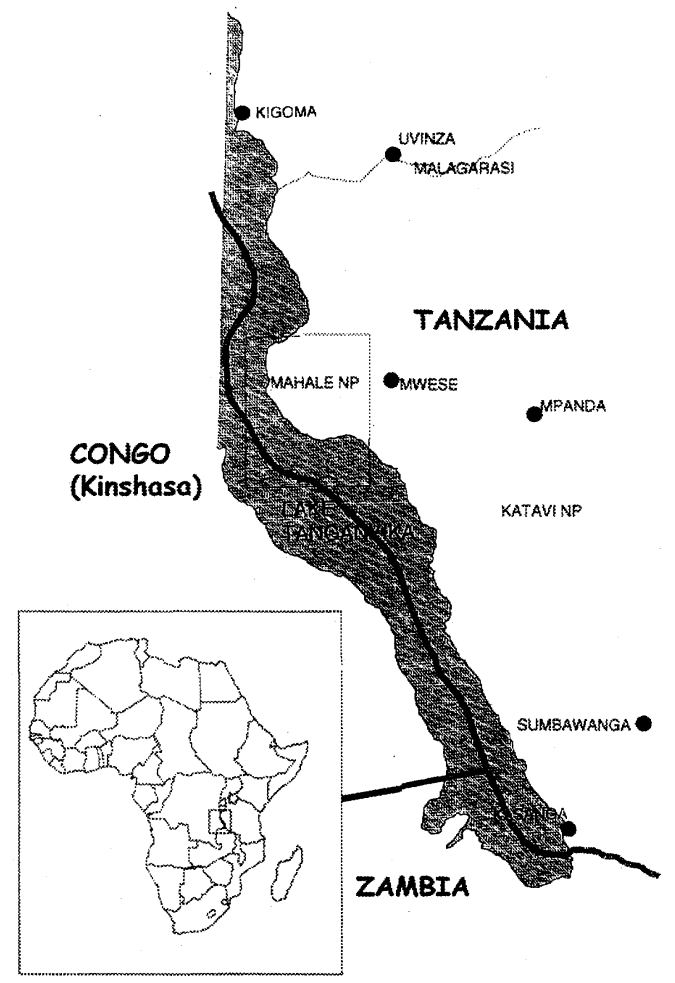

図 1 マハレ山塊国立公園周辺地図 (国立公園内部は困 2 参照)
きたい。

\section{地理とアクセス}

マハレ山塊国立公園は, 東経約 $30^{\circ}$ ・南緯約 $6^{\circ}$, 東アフリカ, タンザニア連合共和国西端の夕 ンガニイカ湖東岸に位置している（図 1 および図 2)。タンガニイカ湖沿いに約 $150 \mathrm{~km}$ 北にあるキ ゴマの町がアクセスの拠点となる。タンザニア最 大の都市ダル・エス・サラームからキゴマまでは,

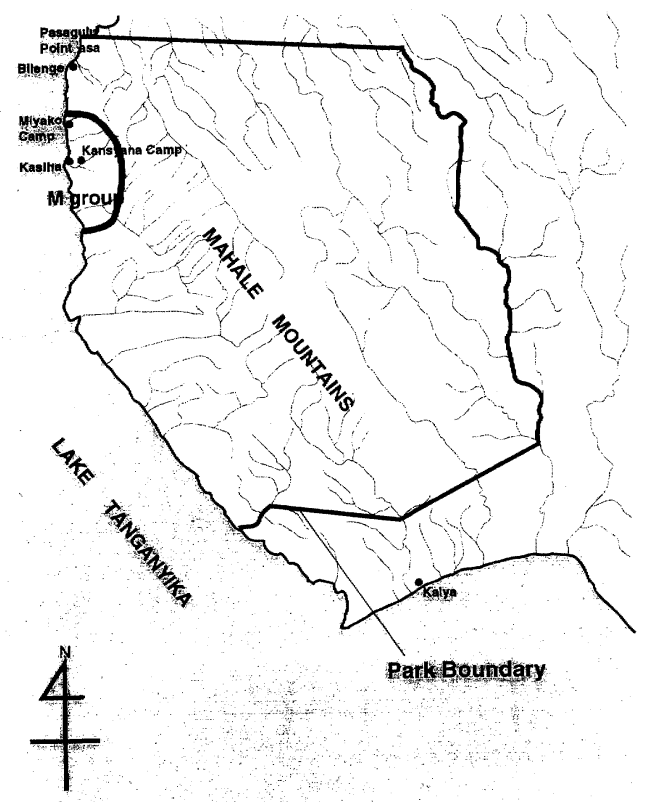

図 2 マハレ山塊国立公園地図. 黒太線は公園境界線, 網掛け太線は M グループの遊動域を示す. 
エア・タンザニアの飛行機が週二便, タンザニア 鉄道の列車が週 6 日走っている。所要時間は, 飛 行機で約三時間, 列車で二泊三日である。

キゴマは小さな町であるが, ブルンジ，ザンビ ア，コンゴ民主共和国（旧ザイール）を結ぶ国際 港となっているため，さまざまな人々が集まり， 物は比較的豊富である。キゴマからマハレまでは, 陸路によるアクセスは困難であり, タンガニイカ 湖がほとんど唯一のアクセス手段となる。チャー ター・ボートか, タンガニイカ湖を南北に走る週 二便の定期汽船 (リエンバ号とムォンゴーゾ号) が利用可能である。汽船は途中いくつかの集落の 沖に停泊するが，マハレへは，国立公園の北方に あるラゴサ（ムガンボ）という集落で下船する。 ラゴサからは, 小さなボートに乗り移り約二時間 ほどで国立公園の管理事務局があるビレンゲを経 て，調查地であるカソゲ地域に到着する。

公園の広さは約 $1,600 \mathrm{~km}^{2}$ で, 湖と山地によっ て形作られる地形が特殊な植生を発達させている。 タンガニイカ湖は湖面自体が標高約 $800 \mathrm{~m}$ あり, 赤道に近いわりには冷涼な気候である。マハレ山 塊は標高 $2,462 \mathrm{~m}$ のンクングェ山を主峰とし, 北 西から南東方向へと走っている。この山塊が湖か らの湿った空気を遮断し, 雨季には山塊の西側に 激しい雨をあたらす。山に降り注いで集められた 雨水は, いくつもの渓流となってタンガニイカ湖 へと流れ込む。これらの渓流のいくつかは雨の降 らない乾季にも水を残す。こうして，山塊の西側 には $1,800 \mathrm{~m}$ 以上に山地林, 山麓には低地林 (力 ソゲ・フォレスト) が発達している。

概して, 山塊と湖に挟まれた西側は湿潤, 山塊 の東側は乾燥しているといえる。マハレでのチン パンジーの長期的な研究はおもに湿潤な山塊の西 側でおこなわれており，国立公園の管理事務局も また湖のほとりにある。

国立公園の東側はほとんど訪れる人もなく, 公 園の管理の手も十分行き届いているとはいえない。 乾季には国立公園の外で放たれた焼畑の火や，密 猟者の放った火が公園の東側に侵入し, 河辺林を 除いたほとんどの地域が焼き尽くされている (Nakamura \& Fukuda, 1999)。その火はマ八
レ山塊の主稜にまで達し，ときおりカソゲ地域か らむ稜線に野火を確認することができる。この地 域には, ゾウ, ライオン, バッファロー, ハーティ・ ビーストなどのサバンナ性の動物が多いが，乾季 にあわずかに残される河辺林を利用してチンパン ジーも生息している。このような, マハレの中で あ最あ乾燥している地域のチンパンジーについて は,いまだほとんよ゙詳しい調査はおこなわれてい ない。

\section{気 候}

研究が継続されてきたマハレ山塊の西側では, 1973 年以降毎日降雨量と最高・最低気温が記録 されてきた。年間降水量は, 森林帯で約 1,600 2,200 mm, 疎開林帯で約 1,200 1,500 $\mathrm{mm}$ である。明確な雨季 (10月から 5 月) と乾季 (6月から 9 月) があり (図 3), 1 月から 2 月頃に 雨の少ない小乾季があることもある。1975 年か ら 1988 年の年間降雨量の変化を見ると隔年で増 減する傾向があることが分かる（図 4)。

平均最高気温は, 乾季で約 $29 \sim 30^{\circ} \mathrm{C}$, 雨季で 約 $27 \sim 28^{\circ} \mathrm{C}$ で, 平均最低気温は乾季で約 $16 \sim 18$ ${ }^{\circ} \mathrm{C}$, 雨季で $18 \sim 20^{\circ} \mathrm{C}$ であ（図 3 ）。すなわち, 乾季の方が雨季よりあ気温の差が激しい。乾季の 明け方にはときおり $13^{\circ} \mathrm{C}$ 台まで気温が下がるこ とあある。

\section{植物相とチンパンジーの食物}

マハレでは,これまでの研究によって 550 種 以上の植物について現地名之学名との対応辞書が 編集されている (Nishida \& Uehara, 1981)。し かし，この辞書はいまだに完全なものとはいえず， 現在新たに同定された植物種を含めた改訂版を作 成中である。

さらに, マハレのチンパンジーの食物リストも 編集されている(Nishida \& Uehara, 1983)。こ れによると, マハレのチンパンジーは少なくとも 198 の植物種から 328 の食物アイテムを利用す ることが確認されており，この数は研究が進むに したがって増加している。これは他の地域から報 告されているものよりも多い。例えば, 同じタン 


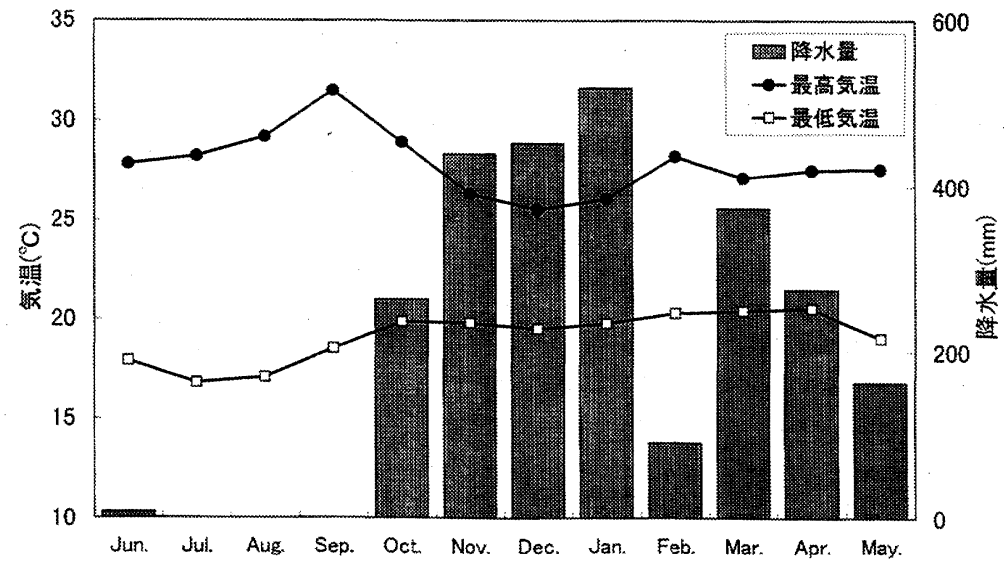

図 31997 年 6 月から 1998 年 5 月のマハレ森林帯 (カンシアナ・キャンプ) の月別降雨量之平均最高・最低気温

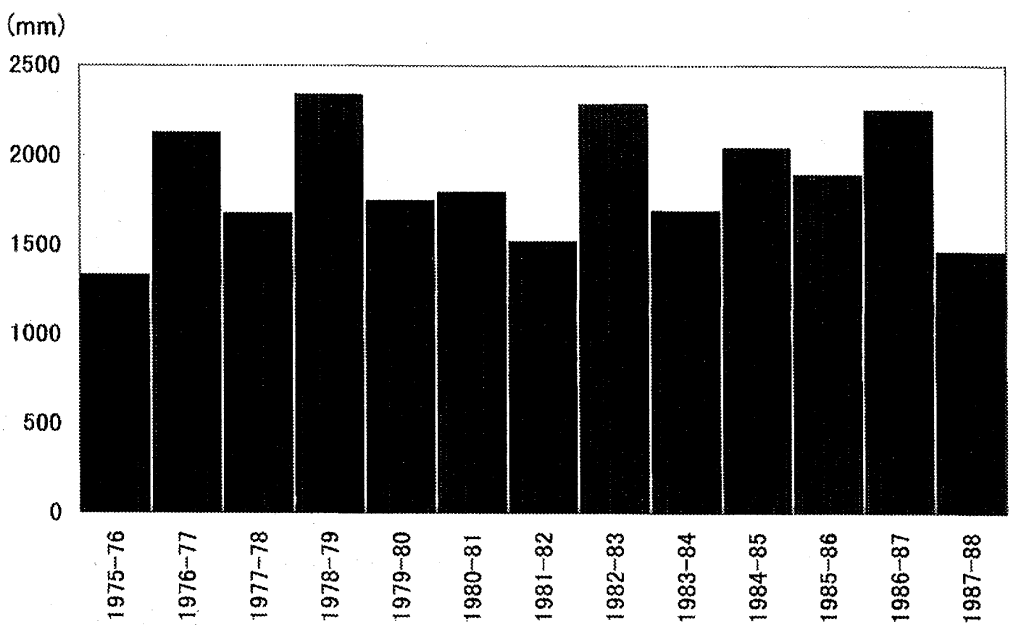

図 4 1975 1988 年のマハレ森林帯 (カンシアナ・キャンプ) の年間降雨量 の推移 (Takasaki et al., 1990 より作図)

ザニアのゴンベ国立公園では 141 の植物種から 184 の食物アイテム (Wrangham, 1975), ギニ アのボッソウでは 156 の植物種から 205 の食物 アイテム (Sugiyama \& Koman, 1987) を利用 することが知られている。また, Nishida (1991) は, マハレの植物をチンパンジーの食物としての 重要度別に分類した。すべての種が網羅されてい るわけではないが，それぞれの食物の味について の記載むある。

一般的に, チンパンジーにとって重要な食物と なっているのは果実である。マハレで季節ごとに
チンパンジーの遊動に大きな影響を与える主要な 果実種 (Nishida，1991）を表 1 に示した。この 他に数々のイチジク類む食物としてよく利用され る。人間が持ちこんだ栽培植物であるレモン，グ アヴァ, マンゴーの果実などあ利用される (Takahata et al., 1986) が, ゴンベ (Wrangham, 1975) やボッソウ (Sugiyama, 1981) のチンパ ンジーが頻繁に利用するアブラヤシは, マハレに あふんだんにあるにあかかわらず一切利用しない。 もちろん, チンパンジーが利用するのは果実だけ ではない。様々な植物の葉, 䯣, 花, 樹皮など, 
表 1 マハレのチンパンジー（M グループ）の主用な食 物となる果実植物

\begin{tabular}{llr}
\hline 科名 & 種名 & \multicolumn{1}{c}{ 利用月 $\cdots$} \\
\hline キョウチクトウ科 & Saba comorensis $*$ & 11 月 2月 \\
ムラサキ科 & Cordia millenii & 3 月〜 7月 \\
アカネ科 & Psychotria peduncularis & 3 月〜 7月 \\
オトキリソウ科 & Garcinia huillensis & 10 月〜11月 \\
ウルシ科 & Pseudospondias microcarpa & 9 月〜11月 \\
オトギリソウ科 & Harungana madagascarensis & 6 月〜 7月 \\
ニクスク科 & Pycnanthus angolensis & 10月〜11月 \\
\hline
\end{tabular}

* これまて S. florida と呼ばれていたが改名された.

**チンパンジーかおもに利用する月 (年によって多少変動がある)

表 2 マハレの植生タイプ (Nishida \& Uehara, 1981 よ り改変)

\begin{tabular}{|c|c|}
\hline A-1 & 高地竹林 (Alpine bamboo forest) \\
\hline A-2 & 山地林 (Montane forest) \\
\hline A-3 & $\begin{array}{l}\text { 低地林, あるいは河辺林 } \\
\text { (Low-altitude forest or gallery forest) }\end{array}$ \\
\hline B-1 & ブラキステギア疎開林 (Brachystegia woodland) \\
\hline B-2 & $\begin{array}{l}\text { ティプロリンクス }=\text { プテロカルプス混交疎開林 } \\
\text { (Diplorhynchus-Pterocarpus mixed woodland) }\end{array}$ \\
\hline B-3 & $\begin{array}{l}\text { ウアパカ=ペリコプシス＝ステレオスペルムム混交疎開林 } \\
\text { (Uapaca-Pericopsis-Stereosperumum woodland) }\end{array}$ \\
\hline B-4 & ウアパカ疎開林 (Uapaca woodland) \\
\hline B-5 & アカシア・サバンナ（Acasia savanna） \\
\hline B-6 & $\begin{array}{l}\text { ミヤンシ・サバンナ } \\
\text { (Solid-stemmed bamboo [Oxytenanthera] savanna) }\end{array}$ \\
\hline B-7 & テルミナリア・サバンナ（Terminalia savanna) \\
\hline B-8 & $\begin{array}{l}\text { プロテア・リキノデンドロン山地サバンナ } \\
\text { (Protea-Ricinodendron montane savanna) }\end{array}$ \\
\hline B-9 & $\begin{array}{l}\text { トンベャ・エリトリナ山地サバンナ } \\
\text { (Dombeya-Erythrina montane savanna) }\end{array}$ \\
\hline B-10 & 高地藪林 (Montane bushland) \\
\hline C-1 & 高地草原 (Montane grassland) \\
\hline
\end{tabular}

種によってさまざまな部位を利用している。

\section{植生環境とチンパンジーの遊動}

前述のように, マハレはタンガニイカ湖とマハ レ山塊に挟まれ，タンザニアでも有数の多雨地帯 となっている。このため, 低地では河辺林が川の 周辺だけでなくよく発達しており, 非常に特異な 植生環境になっている。また, 多様な植生がモザ イク状に分布している。植生は Nishida \&
Uehara (1981) によって14 タイプに分けられて いる（表 2)。これら以外に，主に人間の活動によっ て引き起こされたと考えられる，様々な二次的な 段階が, 特に A-2, A-3 の植生タイプを中心に公 園内に広がっている。

これまでに，マハレではCollins \& McGrew （1988）を除いては定量的な植生調査はほとんど おこなわれてこなかった。Collins \& McGrew （1988）では，一部の地域しか調查されなかった が, 1994 年より Turner がチンパンジー（M グ ループ）の遊動域内全体に及ぶ，植生とフェノロ ジー（果実, 葉, 花など季節変化）の定量的な調 査・分析を開始し，現在む継続して進行中である。 これらの定量的なデータにより，詳細な植生環境 の記述と評価が可能となるであろう。このうち， チンパンジーの食用植物の量と分布については, 予備的な報告がある (Itoh et al., 1998)。

チンパンジーはおすに食物の利用可能性に応じ て遊動ルートを大きく変化させると考えられてい る。図 5 には，観察されたサブ・グループ（パー ティー）の日ごとの遊動ルートが示してある。こ の例では, 乾季の 7 月には全遊動域の南半分で比 較的広いエリアを遊動し，山の上（地図右手）に あ行くことが多いことが分かる。一方，雨季の 11 月には全遊動域の北半分をおむに利用しており， より平坦な地域を集中的に遊動していることが分 かる。また，こうした季節的な変化は年により異 なる様相を示す。このような変化の様相はいまだ 体系的に把握されていないが, 前述した植物のフェ ノロジーのデータとチンパンジーの遊動データを つきあわせることで, 彼らがどのように遊動ルー 卜を決定しているのかが今後はっきりしてくるで あろう。

\section{動物相}

マハレは, 異なる三地域に特徽的な動物種の混 成地帯であるといえる。すなわち，東アフリカ由 来のサバンナ性の種, 南アフリカ由来のサバンナ およびウッドランド性の種, そして, 西アフリカ あるいはコンゴ盆地由来の森林性の種である。マ ハレの動植物は, 東アフリカよりむしろ西アフリ 

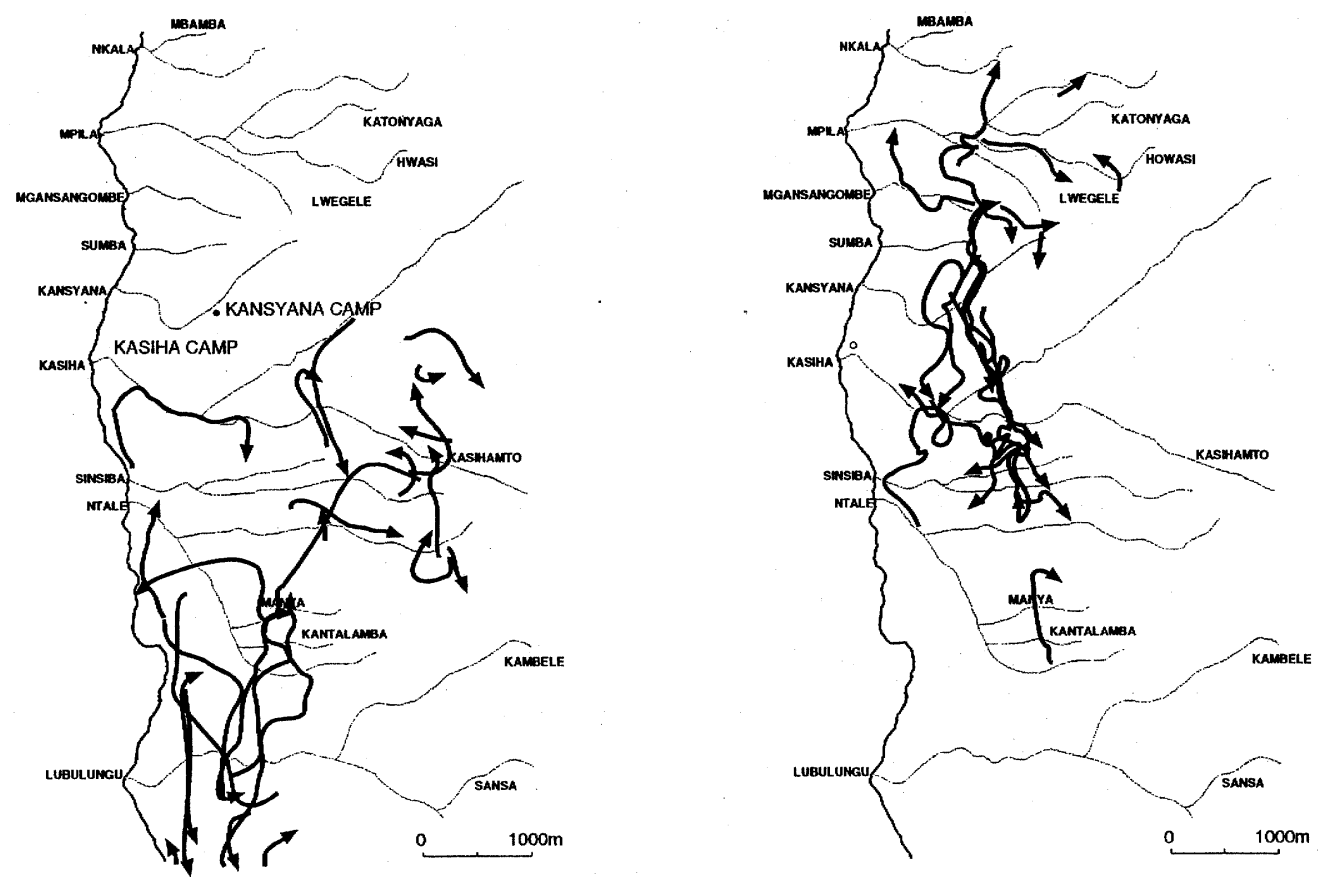

図 5 チンパンジーM グループの遊動ルート 左: 1994 年 7 月 (乾季) 右: 1994 年 11 月 (雨季) (一つの矢 印は観察されたパーティーの一日の遊動ルートを示す)

カに似た様相を呈し，また歴史的に古いと考えら れている種も保持されており, 生物地理学的に興 味深い地域である(伊谷, 1977; Nishida, 1990)。

特に興味深い種をいくつかあげてみよう。フサ オヤマアラシ (Atherurus sp.) は, 西アフリカか らコンゴ盆地にかけて分布する森林性の種で, 東 アフリカからはほかに報告がない。ンクングェ山 のアンゴラクロシロコロブス（Colobus angolensis）は, 同種の他の個体群から地理的に 隔離されているため新亜種の可能性が高い。マハ レのカンムリホロホロチョウの亜種 (Guttera edouardi sethsmithi) は, マハレ以外の西部タン ザニアでは記録がない。他にもフサオマングース (Bdeogale crassicauda), シママングース (Mungos mungo), ブルーダイカー(Cephalophus monticola), シャープグリスボック（Raphicerus sharpei）な よ゙が棲息していることが確認されており，これら の観察記録のいくつかは，既知の分布域を大幅に 広げることを意味している。

マハレの中・大型哺乳類に関しては, ほぼすべ
てが同定されており（Nishida，1990)，そのうち 昼行性のものについては, 分布之密度の推定が なされている (Uehara \& Ihobe, 1998)。霊長 類に関しては, ロリス科が 2 種（フトオガラゴ Galago crassicaudatus, ショウガラゴ Galago senegalensis), オナガザル科が 6 種 (サバンナモ ンキーCercopithecus aethiops, アカオザル $C$. ascanius, ブルーモンキーC. mitis, キイロヒヒ Papio cynocephalus, アンゴラクロシロコロブス Colobus angolensis, アカコロブス C. badius), ショウジョウ科が 1 種 (チンパンジーPan troglodytes schweinfurthii) の計 9 種が確認され ている。

タンガニイカ湖の魚類に関してあ, 多くの固有 種が確認されており, 詳細な研究がなされている (堀, 1993 参照)。また, マハレからは多くの固 有の新種・亜種のチョウ屯報告されており (Kielland, 1978), ショウジョウバエも収集され, 報告されている（Takada \& Uehara, 1987; Okada et al., 1988）。しかし, 食虫類, 翼手類, 
げっ歯類などの小型哺乳類, 鳥類や昆虫などに関 する詳しい調査はいまだ十分とはいえない。その 他，マハレの動物相に関しては, Anon. (1980), Nishida \& Uehara (1983), Sasaki \& Nishida （1999）なよ゙も参照されたい。

\section{謝 辞 、}

タンザニア科学技術委員会, セレンゲッティ野 生生物研究所, タンザニア国立公園, マハレ野生 生物研究センター, マハレ山塊国立公園にはマハ レでの調査を長期にわたって許可していただきま した。野外調查はおもに文部省科学技術研究費に よっておこないました。西田利貞先生には, 本稿 に目を通し適切な助言を頂きました。また，サガ・ シンポジゥムのオーガナイザーである松沢哲郎先 生には本稿発表の機会を与えて頂きました。以上 の方々と機関に厚く御礼申し上げます。

\section{引用文献}

Anonymous 1980: Mahale: Study for the proposed Mahale Mountains National Park, final report May 1980, The Japan International Cooperation Agency, Tokyo.

Collins DA; McGrew WC 1988: Habitats of three groups of chimpanzees (Pan troglodytes) in western Tanzania compared. J. Hum. Evol. 17: 553-574.

堀 道雄 (編) 1993: 川那部浩哉監修, 堀道雄編. タンガ 二イカ湖の魚たち多様性の謎を挆る, 平凡社, 東京.

伊谷純一郎 1977: チンパンジー記序説. 伊谷純一郎編著, チンパンジー記, 講談社, 東京, pp.3-56.

Itoh N, Nishida T, Turner L 1998: Density and distribution patterns of woody vegetation in the Kasoje forest, in view of the food of chimpanzees. A preliminary report. In Nishida $T$ (ed): Resource Use Patterns and Social Structure among Chimpanzees, Nissindo Printer, Kyoto, pp.3-21.

Kielland J 1978: A provisional checklist of the Rhopalocera of the eastern side of Lake Tanganyika. Tijdschrift voor Entomologie 121: 147-237.

Nakamura M 1997: First observed case of chimpanzees predation on yellow baboons (Papio cynocephalus) at the Mahale Mountains National Park. Pan Africa News 4: 9-11.

Nakamura M, Fukuda, F 1999: Chimpanzees to the east of the Mahale Mountains. Pan Africa News 6: 5-7.
Nishida T 1990: A quarter century of research in the Mahale Mountains. In Nishida $\mathrm{T}$ (ed): The Chimpanzees of The Mahale Mountains: Sexual and Life History Strategies, University of Tokyo Press, Tokyo, pp.3-35.

Nishida T 1991: Primate gastronomy. In Friedman MI, Tordoff MG, Kare MR (eds): Appetite and Nutrition, Marcell Dekker Inc., New York, pp.195209.

Nishida T, Uehara S 1981: Kitongwe names of plants: A preliminary listing. Afr. Study Monogr. 1: 109131.

Nishida T, Uehara S 1983: Natural diet of chimpanzees (Pan troglodytes schweinfurthii): long-term record from the Mahale Mountains, Tanzania. Afr. Study Monogr. 3: 109-130.

Okada T, Asada N, Kawanaka K 1988: A result of drosophilid survey in Tanzania. Afr. Study Monogr. 8: 159-163.

Sasaki H, Nishida T 1999: Notes on the flies associated with wild chimpanzees at Mahale Mountains National Park, Tanzania, East Africa. Med. Entomol. Zool. 50: 151-155.

Sugiyama Y 1981: Observation on the population dynamics and behavior of wild chimpanzees at Bossou, Guinea, in 1979-1980. Primates 22: 435444.

Sugiyama Y, Koman J 1987: A preliminary list of chimpanzees' alimentation at Bossou, Guinea. Primates 28: 133-147.

Takada H, Uehara S 1987: Drosophilid flies (Diptera) in the Mahale Mountains National Park, Tanzania: A preliminary report. Afr. Study Monogr. 7: 1519.

Takahata Y, Hiraiwa-Hasegawa M, Takasaki H, Nyundo R 1986: Newly acquired feeding habits among the chimpanzees of the Mahale Mountains National Park, Tanzania. Hum. Evol. 1: 277-284.

Takasaki H, Nishida T, Uehara S, Norikoshi K, Kawanaka K, Takahata Y, Hiraiwa-Hasegawa M, Hasegawa T, Hayaki H, Masui K, Huffman MA 1990: Summary of meteorological data at Mahale research camps, 1973-1988. In Nishida T (ed): The Chimpanzees of The Mahale Mountains: Sexual and Life History Strategies, University of Tokyo Press, Tokyo, pp.291-300.

Uehara S, Ihobe H 1998: Distribution and abundance of diurnal mammals, especially monkeys, at Kasoje, Mahale Mountains, Tanzania. Anthropol. Sci. 106: 349-369.

Wrangham RW 1975: The behavioural ecology of chimpanzees in Gombe National Park, Tanzania. $\mathrm{Ph}$. D. thesis, University of Cambridge. 
(Summary)

\title{
Site Report: The Mahale Mountains National Park, Tanzania
}

\author{
Michio NAKAMURA, Noriko ITOH and Tetsuya SAKAMAKI \\ Laboratory of Human Evolution Studies, Department of Zoology Faculty of \\ Science, Kyoto University
}

More than 30 years have passed since chimpanzee research camp was set up at the Mahale Mountains in Tanzania. Besides the continuous long-term research on chimpanzees, various research and descriptions on climate, plants, vegetation and animals have been made. In this paper, we made general descriptions about not only chimpanzees but also about other various aspects of Mahale which were obtained during the long term research and also some information for people who plan to visit Mahale. For details of chimpanzee research in Mahale, please refer to literature list in our web page (http://gorilla.zool.kyoto-u.ac.jp/ChimpHome /reference.html).

\section{中村美知夫 京都大学大学院理学研究科生物科学専攻} 于606-8502 京都市左京区北白川追分町

Michio NAKAMURA Lab. of Human Evolution Studies, Dept. of Zoology, Faculty of Science, Kyoto Univ. Sakyo, Kyoto, 606-8502, Japan

e-mail: nakamura@jinrui.zool.kyoto-u.ac.jp 